\title{
MEASUREMENTS OF THE CIRCULATION IN CONSTRICTIVE PERICARDITIS BEFORE AND AFTER RESECTION OF THE PERICARDIUM ${ }^{1}$
}

\author{
BY HAROLD J. STEWART, GEORGE J. HEUER, JOHN E. DEITRICK, NORMAN F. \\ CRANE, ROBERT F. WATSON AND CHARLES H. WHEELER
}

(From the New York Hospital, Departments of Medicine and Surgery, Cornell University Medical College, New York City)

(Received for publication April 1, 1938)

Experience is showing that chronic constrictive pericarditis is not an uncommon syndrome. Attention has been directed to it again in recent years. Its recognition has been facilitated by White's (1) historical resumé and analysis of its clinical features. It is of therapeutic importance to recognize this syndrome for it is a cardiac affection that lends itself to surgical treatment as the experience of Churchill (2), Beck and Griswold (3), Blalock (4), and of Stewart and Heuer (5), as well as others, has demonstrated. The clinical manifestations of this disease have been very well described; the pathological physiology of the circulation has not, however, been sufficiently explored.

In the last two and a half years, we have observed 9 patients suffering from chronic constrictive pericarditis, and in six of these part of the pericardium has been resected by Dr. George J. Heuer. ${ }^{2}$ In them, studies of the circulation have been made before as well as after partial pericardiectomy. One clinical group does not have the opportunity to see large numbers of these patients in a short time, and for this reason this paper records our studies of the circulation in this situation, together with a statement of our experience with surgical treatment.

\section{PLAN OF STUDY}

All patients were admitted to the hospital and remained in bed. The daily fluid intake was limited to 1200 cc., and the salt to 2.0 grams. A high protein diet was given.

Studies of the circulation were made when the patients first came under observation and before we in-

\footnotetext{
1 An abstract of these studies was read before the Association of American Physicians, Atlantic City, May 5, 1937.

2 Since this paper went to press the pericardium was resected from another patient, making seven cases in all (5).
}

stituted drug therapy. Diuretics were then administered and studies were repeated, this time when they were in the best state it was possible for them to attain. Resection of the pericardium was then done. As soon after operation as the patients were able to participate, observations were repeated, as well as later when changes in the clinical state occurred. The patients were discharged from the hospital free of excess fluid and followed in the Cardiac Outpatient Clinic, from which they were readmitted to the hospital at intervals for repetition of the studies of the circulation.

\section{METHODS}

All observations were made in the morning while the patients were in a basal metabolic state. Measurements of the cardiac output were made by the acetylene method, three samples of gas being taken as first recommended by Grollman (6), and by Grollman, Friedman, Clark, and Harrison (7). During this measurement the patients were sitting in a steamer chair (angle 135 degrees). They were trained beforehand to carry out the procedures. While the patient was at rest, the cardiac rate was counted at intervals of five minutes. At the end of one-half hour the acetylene-air-oxygen mixture was rebreathed. Three samples of gas were taken during each rebreathing period for estimation of the arteriovenous oxygen difference. The first sample was taken after rebreathing 10 to 12 times in 20 seconds, the second after 2 to 3 breaths more, and the third after 2 to 3 additional breaths. All three samples were usually obtained before the end of 30 seconds. Samples were taken during expiration. Two to three periods of rebreathing were carried out on each patient. Shortly afterward, the oxygen consumption was measured with a Benedict-Roth spirometer. After a short pause, the vital capacity was measured, and height and weight recorded. In succession, sufficient time being allowed between each procedure for the patient to return to a basal metabolic state, an electrocardiogram was taken, the arm to tongue circulation time recorded, the venous pressure estimated, and the blood pressure measured; finally an $x$-ray photograph of the heart was made at a distance of two meters.

The arm to tongue circulation time was estimated by the use of decholin (8). Five cc. of a 20 per cent solution were injected rapidly ( 1 to 2 seconds) through an 18-gauge needle into an antecubital vein while the patient was lying quietly in the supine position. This was re- 
peated in one and one-half minutes after the response to the first test had been elicited. The time was recorded from the beginning of the injection until the patient perceived the bitter taste.

The venous pressure was measured by the direct method (9), using a large antecubital vein, the arm being placed on a level with the right auricle. Normal pressures by this method range from 4.0 to $10.0 \mathrm{~cm}$. of saline. The antecubital vein of one arm was reserved for the injection of decholin and of the other arm for the measurement of venous pressure. In subsequent measurements the vein was entered at the site first punctured.

$\mathrm{X}$-ray photographs of the heart were taken with the patient in the standing position, in full inspiration, at a distance of two meters. ${ }^{8}$ Measurements of the cardiac area were carried out by the technique of Levy (10) and estimations of volume were made as recommended by Bardeen (11). Special $x$-ray exposures in the anterioposterior as well as in the lateral positions were taken for the detection of calcification. Examination under the fluoroscope was also carried out. In certain patients photographs of the eyegrounds were made for definition of the vessels. Infra-red photographs of the patients were taken to record the state of the peripheral veins. The patients assumed as nearly as possible exactly the same position for each observation in order to assure uniformity from this point of view. In addition, each procedure in the observation was carried out by the same investigator.

The six patients who were operated upon and in whom observations were made both before and after partial pericardiectomy form the subject of this paper.

\section{RESULTS}

The data are recorded in Tables I and II and certain of the data are summarized in Figure 1.

The arteriovenous oxygen difference before operation was increased in all except one (Case $6,59.7)$, the range being from 71.5 to $88.6 \mathrm{cc}$. After operation when the patients were in their best state, it decreased in all patients and only one fell outside of the normal range, which was then 51.4 to $68.7 \mathrm{cc}$.

The cardiac output per minute and cardiac index 4 were decreased in all except one patient (Case 6, 2.16 liters), the range of the index being 1.35 to 1.82 liters. After operation it increased and ranged between 1.80 to 2.72 liters, and was below normal in only one (Case 4 ).

8 The authors are deeply indebted to the X-ray Department of the New York Hospital for their cooperation in this investigation.

4 Cardiac index $=$ liters per square meter per minute.
The stroke volume was decreased and the range was from 20 to $42 \mathrm{cc}$. per beat. After operation it increased and ranged from 33 to $50 \mathrm{cc}$. per beat.

The venous pressure was elevated in every case, the range being 17.9 to $24.0 \mathrm{~cm}$. After operation it fell and when the patients were in their best state the range was 8.3 to $16.7 \mathrm{~cm}$.

The arm to tongue circulation time ranged from 13.5 to 29.8 seconds before operation; in short, it was prolonged. After operation the range was 7.3 to 17.1 seconds when the patients were in their best state.

There was no consistent behavior of the heart rate. In certain patients it was elevated before operation and slowed afterward, and in others the reverse happened. The basal metabolic rate was not altered significantly in this syndrome, nor was it changed by operation.

The vital capacity before operation was not lowered if the pleural cavities were free of fluid. In certain patients it decreased and in others it increased after operation. Decrease after operation was in part due to the flexible thoracic cage resulting from removal of the ribs.

Infra-red photographs revealed marked distention of and increase in the number and caliber of the venous channels before operation. As improvement occurred after operation there was progressive decrease in their number and caliber (Figure 2).

\section{CLINICAL COURSE OF PATIENTS}

After operation there were 3 trends : (1) Clinical improvement was rapid and striking, and associated with this were changes toward normal of the measurements of the circulation (Tables I and II, Figure 1). In two patients "cure" was a matter of months (Cases 1 and 2). (2) In one (Case 3), clinical improvement was slow and gradual, to cure in approximately 1 year after operation (Tables I and II); in her, the measurements of the circulation showed gradual changes. (3) Three patients improved gradually after operation; their condition has now become stationary (Cases 4, 5, and 6). They are better than before the operation and are ambulatory, and there have been changes in the circulation toward normal (Tables I and II). 


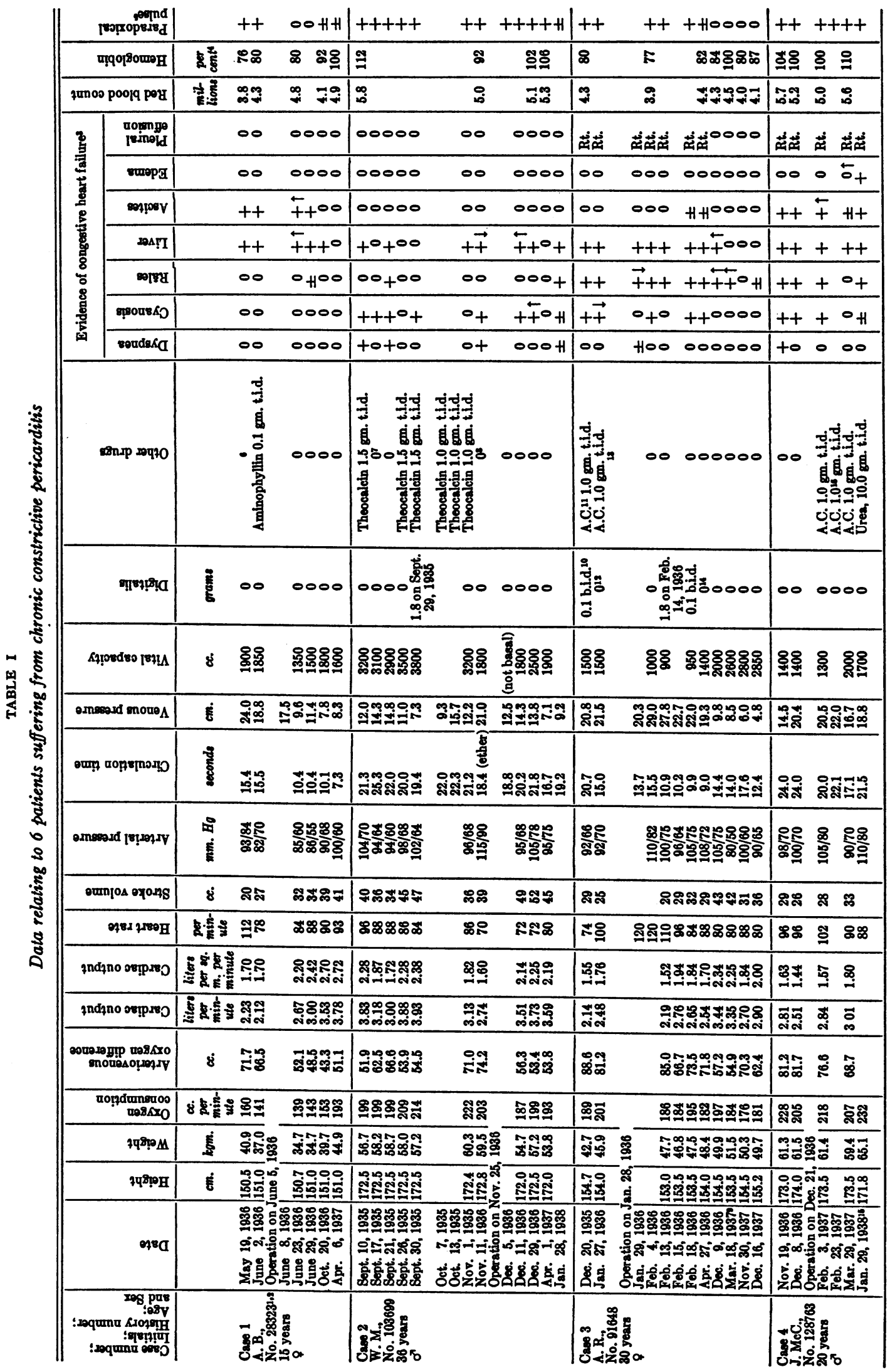




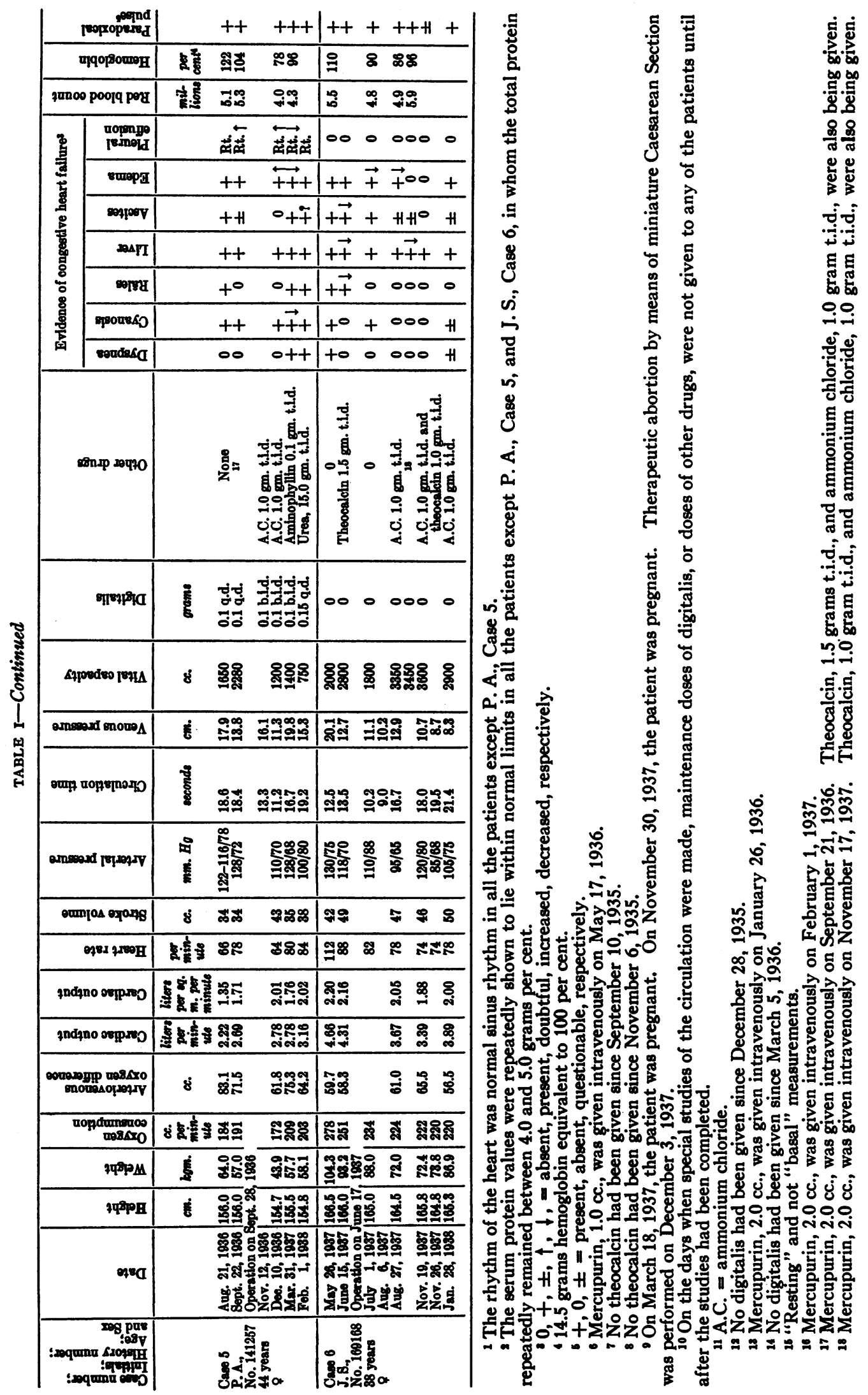


TABLE II

Additional data relating to 6 cases of chronic constrictive pericarditis *

\begin{tabular}{|c|c|c|c|c|c|c|c|c|c|}
\hline $\begin{array}{c}\text { Case } \\
\text { number; } \\
\text { Initials; } \\
\text { and } \\
\text { History } \\
\text { number }\end{array}$ & Time & $\begin{array}{l}\text { Duration } \\
\text { of } \\
\text { diseseef }\end{array}$ & Egtiol & Heart sise & $\begin{array}{l}\text { Caloifion- } \\
\text { thon of } \\
\text { peri- } \\
\text { cardinm }\end{array}$ & Fluoroseopy of heart & Electroesardiogram & Result & $\begin{array}{l}\text { Time } \\
\text { since } \\
\text { opers- } \\
\text { tlon } \ddagger\end{array}$ \\
\hline \multirow[t]{2}{*}{$\begin{array}{l}\text { Case } 1 \\
\text { A. B. } \\
\text { Number } \\
28323\end{array}$} & $\begin{array}{l}\text { Before } \\
\text { operation }\end{array}$ & $\begin{array}{l}5 \text { years } \\
6 \text { months }\end{array}$ & unk. & Very amall & Present & Very small pulsations & $\begin{array}{l}\text { B1. R.A.D. QRS, } 1,2 \text { and } T_{1,2,3} \text { low } \\
\text { ampl. } T_{2,2} \text { cove shaped. Axis shift } \\
37^{\circ}\end{array}$ & & \\
\hline & $\begin{array}{l}\text { After } \\
\text { operation }\end{array}$ & & & Larger & Present & Very good pulsations & Axls shift $22^{\circ}$. No other change & Cured & 1 year \\
\hline \multirow{2}{*}{$\begin{array}{l}\text { Case } 2 \\
\text { W. M., } \\
\text { Number } \\
103699\end{array}$} & $\begin{array}{l}\text { Before } \\
\text { operation }\end{array}$ & $\begin{array}{l}1 \text { year } \\
4 \text { months }\end{array}$ & unk. & Large & 0 & $\begin{array}{l}\text { 8l. of lt. side, none of rt. side. No } \\
\text { downward shift, sl. It. shift }\end{array}$ & $\begin{array}{l}\text { R.A.D. QRS } 1,2,2 \text { low ampl. } T_{1,2} \text { neg. } \\
\text { Axis shift } 0^{\circ}\end{array}$ & & \\
\hline & $\begin{array}{l}\text { After } \\
\text { operation }\end{array}$ & & & Smaller & $\mathbf{0}$ & Good palsations & $\begin{array}{l}\text { R.A.D. QRSR,2, still low ampl. T1,2,8 } \\
\text { inor. ampl. Adis shift } \theta^{\circ}\end{array}$ & Cured & $\begin{array}{l}1 \text { year } \\
4 \text { months }\end{array}$ \\
\hline \multirow{2}{*}{$\begin{array}{l}\text { Case } 3 \\
\text { A. R. } \\
\text { Number } \\
91648\end{array}$} & $\begin{array}{l}\text { Before } \\
\text { operation }\end{array}$ & 4 months & tbo. & 81. enlarged & 0 & $\begin{array}{l}\text { Deor. pulastions of rt. aur. and rt. } \\
\text { vent. }\end{array}$ & $\begin{array}{l}\text { 81. R.A.D. QRS } 1,2,8 \text { low ampl. T1,2,2 } \\
\text { low ampl. Aris shift } 11^{\circ}\end{array}$ & & \\
\hline & $\begin{array}{l}\text { After } \\
\text { operation }\end{array}$ & & & Smallex & $\mathbf{0}$ & Ercollent pulastions & No change. Axis ghift $6^{\circ}$ & Cured & 2 years \\
\hline \multirow{2}{*}{$\begin{array}{l}\text { Case } 4 \\
\text { J. McC., } \\
\text { Number } \\
128763\end{array}$} & $\begin{array}{l}\text { Before } \\
\text { operation }\end{array}$ & 7 months & onk. & Large & 0 & No motion lower 1/3 of heart & $\begin{array}{l}\text { 81. L_A.D. QRS } \\
\text { cove shaped. Aris shift } 11^{\circ}\end{array}$ & & \\
\hline & $\begin{array}{l}\text { After } \\
\text { operation }\end{array}$ & & & $\begin{array}{l}\text { No ohange in } \\
\text { sise, but ahape } \\
\text { changed }\end{array}$ & $\mathbf{0}$ & Iner. motion bat none of rt. vent. & $\begin{array}{l}\text { No axds deviation. Iner. ampl. of } \\
\text { QRE } 1,2,2 \text { Axts shift } 18^{\circ}\end{array}$ & Improved & 3 moanths \\
\hline \multirow{2}{*}{$\begin{array}{l}\text { Case } 5 \\
\text { P. A. } \\
\text { Number } \\
141257\end{array}$} & $\begin{array}{l}\text { Before } \\
\text { operation }\end{array}$ & $\$$ & unk. & Large & Present & Decr. pulsations of rt. aur. & 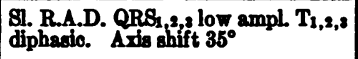 & & \\
\hline & $\begin{array}{l}\text { After } \\
\text { operation }\end{array}$ & & & $\begin{array}{l}\text { Not much } \\
\text { change }\end{array}$ & Present & $\begin{array}{l}\text { Iner, along lt. bat almost none of } \\
\text { rt. aur. and rt. vent. }\end{array}$ & No ahange. Ads ghift $30^{\circ}$ & Improved & 1 year, \\
\hline \multirow{2}{*}{$\begin{array}{l}\text { Case } 6 \\
\text { J. 8. } \\
\text { Number } \\
169168\end{array}$} & $\begin{array}{l}\text { Before } \\
\text { operation }\end{array}$ & 6 years & unk. & Small & $\begin{array}{l}\text { Not seen } \\
\text { in I-ray }\end{array}$ & SI pulastions of lt. vent. & 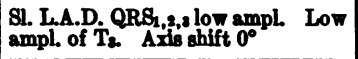 & & \\
\hline & $\begin{array}{l}\text { After } \\
\text { operation }\end{array}$ & & & Larger & $\begin{array}{l}\text { Precent in } \\
\text { miloro. seo. } \\
\text { of pericard. }\end{array}$ & Iner. pulsations & $\begin{array}{l}\text { Bl. I.A.D. QRS, } 2,3 \text { al. Iner. in ampl. } \\
T_{1,2} \text { incr. In ampl. } \Delta \text { xis shift } 30^{\circ}\end{array}$ & Improved & 8 monthe \\
\hline
\end{tabular}

* In this Table the following abbreviations are used:

unk. = unknown

tbc. $=$ tuberculosis

sl. $=$ slight

lt., rt. = left, right, respectively

incr., decr. = increased, decreased, respectively

ampl. = amplitude

neg. = negative

R.A.D., L.A.D. = right and left axis deviation respectively

aur., vent. = auricle, ventricle, respectively

micro. sec. of pericard. = microscopic sections of pericardium

$\dagger$ As estimated from evaluation of patients' history.

$¥$ As of March, 1938.

Edema of ankles was noted 10 years before admission. Symptoms were first noted 2 months before admission.

\section{DISCUSSION}

Our observations show that chronic constrictive pericarditis is characterized by decreased cardiac output per minute and per beat, rise in venous pressure, slowing of the velocity of blood flow, and engorgment of the venous vascular bed. Fluoroscopic examination shows decreased contraction of the heart chambers, and fixation of the heart may be observed. Clinical improvement after operation was associated with changes in all these functions toward normal. There appear to be two essential defects in this syndrome, namely, (1) obstruction to the entrance of blood into the chambers of the heart resulting in decreased filling, and (2) interference with contraction of the heart. There is evidence for the first in (a) the decreased dilatation of the heart in diastole under fluoroscopic examination and at operation and $(b)$ the observation at operation of the thickened pericardium which was not capable of much distention and may have been calcified. (c) Infra-red photographs revealed distention of the peripheral veins. $(d)$ The elevated venous pressure is evidence that there is ample 
A CURED

B IMPROVED

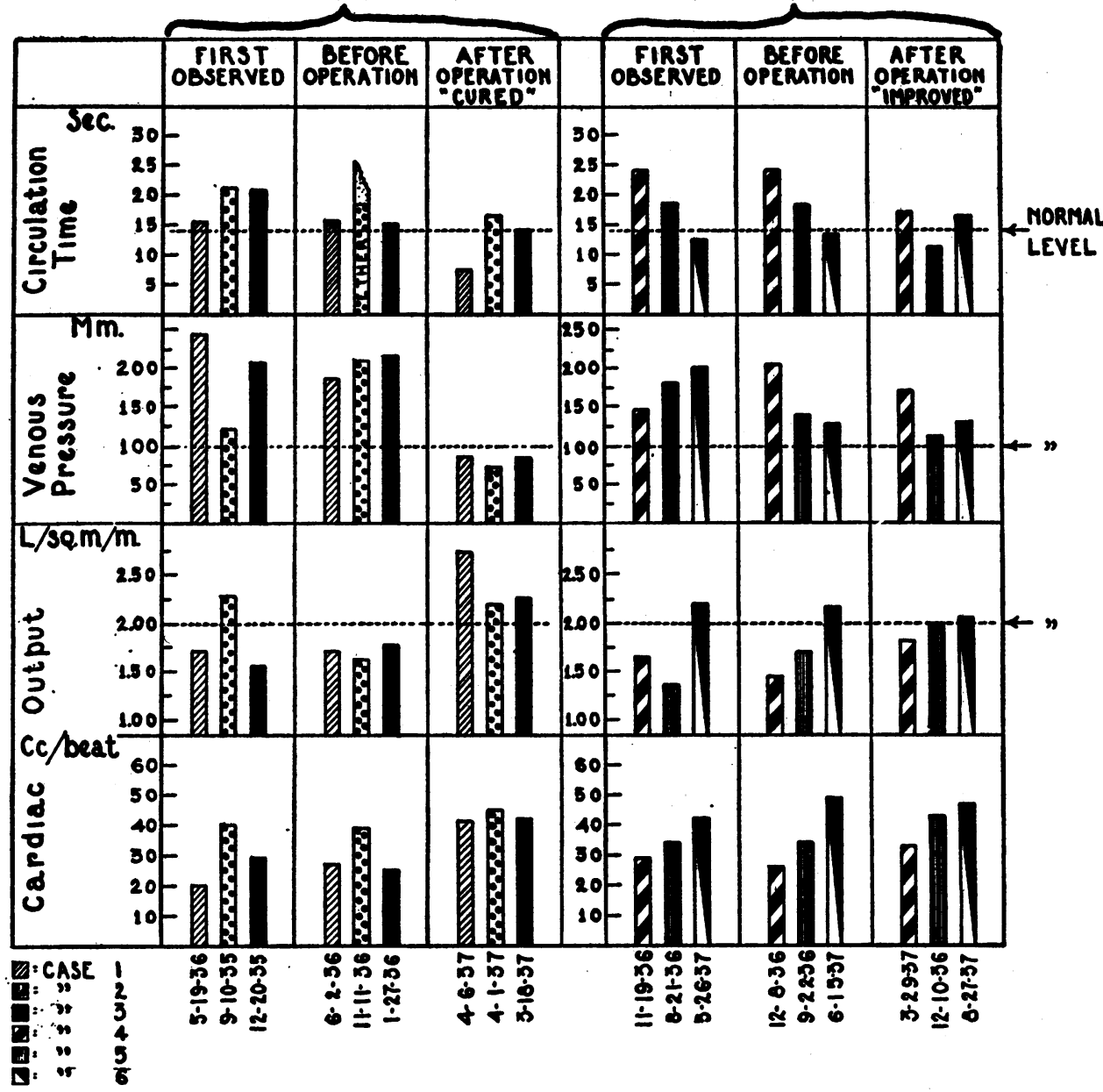

FIG. 1

Data relating to 3 patients "cured" by operation (A) and 3 "improved" by operation (B).

blood available for the heart. With respect to contraction, impairment is inferred from the $(a)$ decreased extent of contraction on fluoroscopic examination and at operation, as well as from (b) the examination of the thickened unyielding pericardium incapable of much change during contraction. These two defects result in decrease in cardiac output, per beat and per minute, and piling up of blood on the venous side, accounting for increase in venous pressure and slowing of the velocity of blood flow. The heart may be unusually small or not much enlarged. ${ }^{5}$ Removal of the pericardium results in alteration of these

5 The cardiac silhouette is made up of cardiac shadow plus the shadow of the thickened pericardium. two defects, in short, in removing obstruction to blood entering the heart, allowing the heart to stretch in diastole, and increase in extent of contraction; these account for changes in the circulation which have been recorded after operation. Parallel with improvement in circulation after operation, clinical improvement occurs.

These observations with respect to cardiac output and venous pressure are in accord with those reported by Burwell and his associates $(12,13)$, and by Beck and Cushing (14).

The delay in improvement of certain patients after operation may be due in part to dilatation of the region of the heart from which the pericardium has been resected, and in part to ob- 


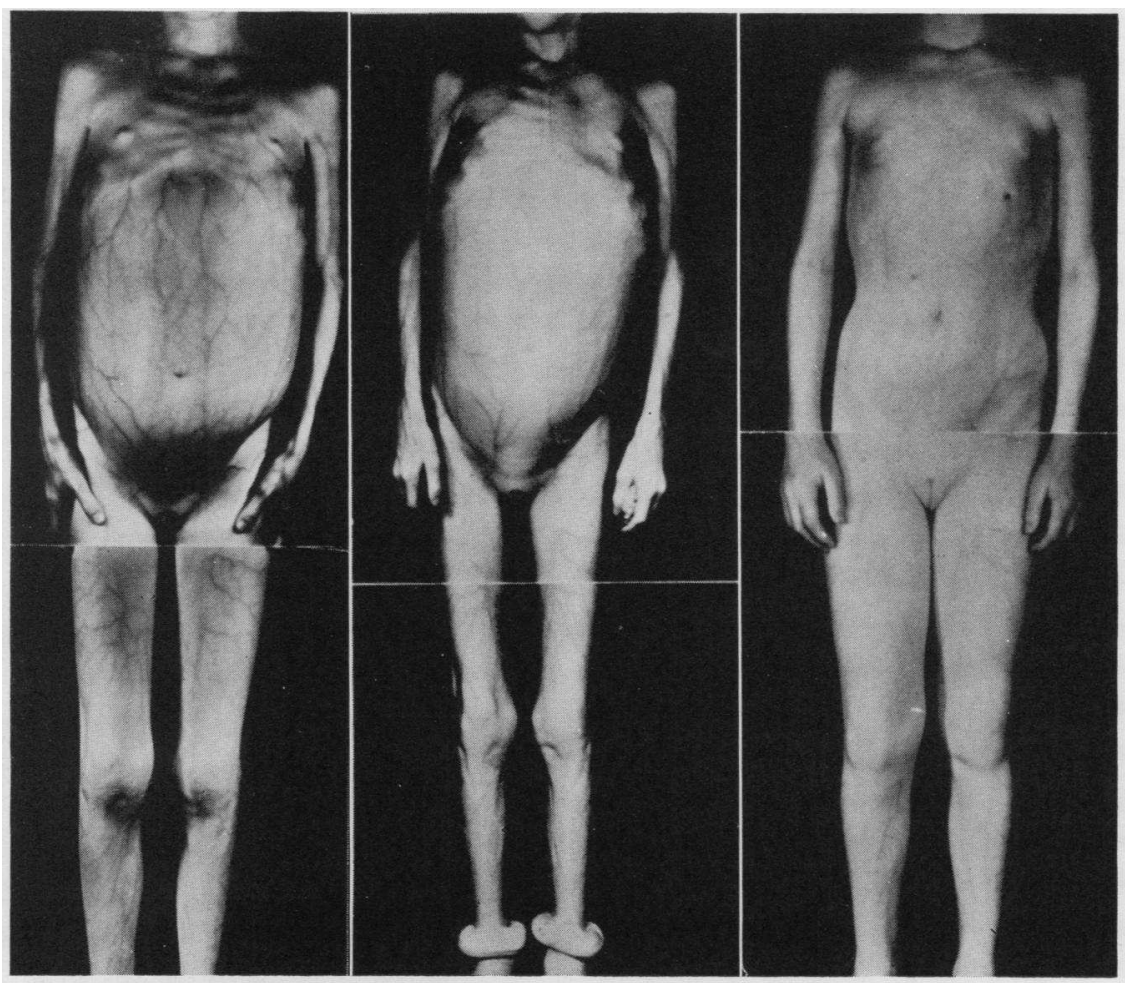

FIG. 2

Infra-red photographs of A.B. (Case 1), in whom operation was followed by “cure." Photograph A was made on May 20, 1936; B on June 29, 1936, 20 days after pericardiectomy, and C on April 4, 1937, approximately 10 months after operation. Attention is directed to the decrease in venous channels, to the patient's growth and development, and to change in flare of the ribs with the elimination of the chronic ascites from which the patient had suffered five and a half years.

struction not having been sufficiently relieved. At operation, the heart bulged through the window which was made in the pericardium and undue stretching of this muscle may have resulted. It may require time for this muscle to regain " tone."

Three patients (Cases 2, 3, and 4) were observed from the stage of pericarditis with effusion through the stage of constriction. In them, signs of obstruction disappeared with absorption of the pericardial fluid, but increased rapidly when formation of adhesions and constriction began and was associated with rapid parallel rise in venous pressure, and circulation time, and decrease in cardiac output.

The use of digitalis appears to be contraindicated except under certain circumstances. Stewart and his associates have shown that digitalis decreases cardiac size $(15,16,17)$ and increases the extent of ventricular contraction $(18,19,20)$.
In the presence of constrictive pericarditis, the size of the heart may already be restricted and the cavities small, and further decrease in its size may not be beneficial but may increase the obstruction. On the other hand, the heart is probably contracting as fully as possible while it is attached to the unyielding thickened pericardium. One patient (Case 5) exhibiting auricular fibrillation was under the influence of digitalis when she came under observation. Its use seemed essential to maintain a slow heart rate, and it did not appear justifiable to withdraw the drug. To one patient (Case 3 ), exhibiting normal sinus rhythm, the drug was given after resection of the pericardium. In this instance, increase in cardiac output and fall in venous pressure occurred, effects which were to be expected $(15,16,17)$, (Table I). Change in size of the heart could not be estimated because of the presence of fluid 
in the right pleural cavity. Digitalis was given to another patient (Case 2) exhibiting normal sinus rhythm. We were unable to state the stage of the pericardiatilesion at the time of exhibition of the drug; it was probably in the stage of absorption of pericardial fluid and early formation of adhesions. The patient was taking theocalcin at the time the first observations were made (Table I). When the drug was discontinued there was rise in venous pressure, slowing of circulation time and decrease in cardiac output. When it was given again the venous pressure fell, the circulation time decreased, and cardiac output increased, and all the measurements were in the normal range. We were unable to evaluate the effects of giving digitalis, 1.8 grams, on September 29, 1935. The control measurements were made 4 days beforehand and spontaneous changes which would invalidate the comparison may have occurred in the circulation in this interval. The effects of theocalcin can, however, be evaluated and were similar to those already recorded by Stewart and Cohn (15).

Case 6 calls for comment. Except for the elevated venous pressure, the measurements of the circulation were in the normal range before operation. She improved before operation by medical treatment and the use of drugs. She was able apparently to maintain at rest in bed a normal cardiac output per minute and cardiac index and approximately normal output per beat in spite of the very thickened adherent pericardium. Operation resulted only in moderate clinical improvement, and the venous pressure fell to normal. Subtotal thyroidectomy had been performed on this patient early in her illness 6 years before, when it was suspected that heart failure was caused by hyperthyroidism. Whether this accounted for the deviation of the patient from the pattern of the other patients, we are unable to state. The circulation was not maintained at the expense of an elevated heart rate, nor was there anemia (21). The plasma protein in this patient remained low although she was given a high protein diet. Before operation, diuretics were ineffectual in this patient. After operation, however, urine outputs of 5 liters a day resulted from $2.0 \mathrm{cc}$. injections of mercupurin, and $16 \mathrm{kgm}$. of weight were lost in 6 weeks (Table I).

The partition of the circulation time was studied in 4 patients (Table III). The arm to tongue circulation time was measured by the use of decholin (D), the arm to lung time by the injection of ether (E) (22), and the lung to respiratory center by the inhalation of carbon dioxide (C) (23). D minus $\mathrm{E}$ should approximate the value of $\mathrm{C}$, which was found to be the case when observations were made (Table III). The ether

TABLE III

Data relating to partition of circulation time in 4 cases

\begin{tabular}{|c|c|c|c|c|c|c|}
\hline \multirow[b]{2}{*}{ Patient } & \multirow[b]{2}{*}{ Date } & \multirow[b]{2}{*}{$\begin{array}{l}\text { Ve- } \\
\text { nous } \\
\text { pres- } \\
\text { sure }\end{array}$} & \multicolumn{4}{|c|}{ Circulation time } \\
\hline & & & $\begin{array}{l}\text { Arm to } \\
\text { tongue. } \\
\text { Decho- } \\
\text { lin (D) }\end{array}$ & $\begin{array}{l}\text { Arm } \\
\text { to } \\
\text { lung. } \\
\text { Ether } \\
\text { (E) }\end{array}$ & $\begin{array}{l}\text { Lung } \\
\text { to re- } \\
\text { spira- } \\
\text { tory } \\
\text { center. } \\
\mathrm{CO}_{2}(\mathrm{C})\end{array}$ & $\begin{array}{l}\text { D-E } \\
\text { should } \\
\text { equal } \\
\text { (C) }\end{array}$ \\
\hline & & $\mathrm{cm}$. & seconds & seconds & seconds & seconds \\
\hline Case 2 & Jan. 28, 1938 & 9.2 & 19.2 & 5.5 & 15.0 & 13.7 \\
\hline Case 4 & Jan. 29,1938 & 18.8 & 21.5 & 13.5 & 9.5 & 8.0 \\
\hline Case 5 & Feb. 1,1938 & 15.3 & 19.2 & 6.0 & 13.5 & 13.2 \\
\hline Case 6 & Feb. 28,1938 & 15.5 & 21.4 & 8.3 & 12.0 & 13.1 \\
\hline
\end{tabular}

arm to lung circulation time was in the normal range in Cases 2, 5, and 6, and prolonged in Case 4. The lung to respiratory center time was prolonged in Cases 2, 5, and 6, and normal in Case 4. In short, no uniformity was apparent.

The effect of pregnancy was observed in one patient (Case 3). Observations made on November 30, 1937 (Table I) when she was 3 months pregnant revealed increase in arteriovenous oxygen difference, decrease in cardiac output per minute and per beat, and in cardiac index, and lengthening of the circulation time, not only on comparison of them with the measurements on March 18, 1937, before pregnancy occurred, but also when restoration to normal was found on December 16, 1937, 13 days after therapeutic abortion.

\section{SUMMARY AND CONCLUSION}

Chronic constrictive pericarditis is usually associated with decrease in cardiac output per minute and per beat, and decrease in the cardiac index. The venous pressure is elevated and the circulation time prolonged, and there is increase in size and caliber of the peripheral venous channels. Rest in bed and medical therapy may occasion clinical improvement with disappearance 
of the accumulations of fluid, and with changes of the circulation toward normal. After operation in those cured, the measurements assumed normal limits and in those "improved" the measurements of the circulation approached normal. In this syndrome the symptoms and signs appear to be a consequence of the defects in circulation which the constricting pericardium occasions. These defects appear to be two: (1) obstruction to entrance of blood into the chambers of the heart and (2) interference with contraction and emptying of the heart. These result in (1) decrease in cardiac output per minute and per beat and (2) piling up of blood on the venous side, which accounts for rise in venous pressure and slowing of the velocity of blood flow. Releasing the heart and removing obstruction by resection of part of the pericardium results in return of these functions toward or to normal levels.

\section{BIBLIOGRAPHY}

1. White, P. D., Chronic constrictive pericarditis (Pick's disease) treated by pericardial resection. Lancet, $1935,2,539$ and 597.

2. Churchill, E. D., Pericardial resection in chronic constrictive pericarditis. Ann. Surg., 1936, 104, 516.

3. Beck, C. S., and Griswold, R. A., Pericardiectomy in the treatment of the Pick syndrome. Experimental and clinical observations. Arch. Surg., 1930, 21, 1064.

4. Blalock quoted by Burwell (13).

5. Stewart, H. J., and Heuer, G. J., Chronic constrictive pericarditis: Dynamics of the circulation and results of surgical treatment. Arch. Int. Med. (In press).

6. Grollman, A., The Cardiac Output of Man in Health and Disease. C. C. Thomas Co., Springfield, 1932, p. 73.

7. Grollman, A., Friedman, B., Clark, G., and Harrison, T. R., Studies in congestive heart failure. XXIII. A critical study of methods for determining the cardiac output in patients with cardiac disease. J. Clin. Invest., 1933, 12, 751.

8. Tarr, L., Oppenheimer, B. S., and Sager, R. V., The circulation time in various clinical conditions determined by the use of sodium dehydrocholate. Am. Heart J., 1933, 8, 766.

9. Taylor, F. A., Thomas, A. B., and Schleiter, H. G., A direct method for the estimation of venous pressure. Proc. Soc. Exper. Biol. and Med., 1930, 27, 867.

10. Levy, Robert L., The size of the heart in pneumonia. A teleoroentgenographic study, with observations on the effect of digitalis therapy. Arch. Int. Med., 1923, 32, 359.

11. Bardeen, C. R., Determination of the size of the heart by means of the x-rays. Am. J. Anat., 1918, 23, 423.

12. Burwell, C. S., and Strayhorn, W. D., Concretio cordis. I. A clinical study, with observations on the venous pressure and cardiac output. Arch. Surg., 1932, 24, 106.

13. Burwell, C. S., and Flickinger, D., Obstructive pericarditis. Effect of resection of the pericardium on the circulation of a patient with concretio cordis. Arch. Int. Med., 1935, 56, 250.

14. Beck, C. S., and Cushing, E. H., Circulatory stasis of intrapericardial origin. The clinical and surgical aspects of the Pick syndrome. J. A. M. A., 1934, 102, 1543.

15. Stewart, Harold J., and Cohn, Alfred, E., Studies on the effect of the action of digitalis on the output of blood from the heart. III. Part I. The effect on the output in normal human hearts. Part II. The effect on the output of hearts in heart failure with congestion, in human beings. J. Clin. Invest., 1932, 11, 917.

16. Stewart, H. J., Crane, N. F., Deitrick, J. E., and Thompson, W. P., Action of digitalis in compensated heart disease. Part I. In the presence of regular sinus rhythm. Part II. In the presence of auricular fibrillation. Arch. Int. Med. (In press).

17. Stewart, H. J., Deitrick, J. E., Crane, N. F., and Wheeler, C. H., Action of digitalis in the uncompensated heart disease. Part I. In the presence of regular sinus mechanism. Part II. In the presence of auricular fibrillation. Arch. Int. Med. (In press).

18. Cohn, A. E., and Stewart, H. J., Evidence that digitalis influences contraction of the heart in man. J. Clin. Invest., 1924, $1,97$.

19. Cohn, A. E., and Stewart, H. J., The relation between cardiac size and cardiac output per minute following the administration of digitalis in normal dogs. J. Clin. Invest., 1928, 6, 53.

20. Cohn, A. E., and Stewart, H. J., The relation between cardiac size and cardiac output per minute following the administration of digitalis in dogs in which the heart is enlarged. J. Clin. Invest., 1928, 6, 79.

21. Stewart, H. J., Crane, N. F., and Deitrick, J. E., Studies of the circulation in pernicious anemia. J. Clin. Invest., 1937, 16, 431.

22. Hitzig, W. M., The use of ether in measuring the circulation time from the antecubital veins to the pulmonary capillaries. Am. Heart J., 1935, 10, 1080.

23. Gubner, R., The use of $\mathrm{CO}_{2}$ inhalation and of alphalobeline as tests of circulation time. Read before the Scientific Meeting of the New York Heart Assoc., New York Acad. Med., February 1st, 1938. 